\title{
Application of Fluorescence in Situ Hybridization to Detect MYCN Amplification on Paraffin-embedded Tissue Sections of Neuroblastoma - Single Institute Study.
}

\section{Dorota Winnicka ( $\sim$ dwinnicka@o2.pl)}

Medical University of Lublin: Uniwersytet Medyczny w Lublinie https://orcid.org/0000-0001-8056-4460

Mariusz Babicz

Medical University of Lublin Main Library: Uniwersytet Medyczny w Lublinie

\section{Borys Styka}

Uniwersytet Medyczny w Lublinie

\section{Paulina Skowera}

Uniwersytet Medyczny w Lublinie

\section{Joanna Zawitkowska}

Uniwersytet Medyczny w Lublinie

\section{Monika Lejman}

Uniwersytet Medyczny w Lublinie

\section{Research article}

Keywords: neuroblastoma, MYCN amplification, fluorescent in situ hybridization (FISH), paraffin tissue sections, prognostic factors

Posted Date: October 26th, 2020

DOI: https://doi.org/10.21203/rs.3.rs-95672/v1

License: (c) (i) This work is licensed under a Creative Commons Attribution 4.0 International License. Read Full License 


\section{Abstract}

\section{Background}

Neuroblastoma is the most common extracranial solid tumour in children. Amplification of the $M Y C N$ gene was observed in approximately $20-30 \%$ of tumours. It is strongly correlated with advanced stage of disease, rapid tumour progression, resistant to chemotherapy and poor outcome independent of patient age and stage of advanced disease. Amplification of the MYCN identify high-risk patients.

\section{Methods}

To assess neuroblastoma tumours with $M Y C N$ amplification we used paraffin-embedded tissue sections in 57 patients by fluorescent in situ hybridization (FISH).

Results

Twenty-eight ( $49,1 \%$ ) of patients had localized neuroblastoma ( $1-3$ stages), 5,3\% stage $4 S$, and $45,6 \%$ stage 4 disease. Thirty-eight $(66,7 \%)$ of patients had got abdominal/adrenal mass at diagnosis. Twentyseven $(47,4 \%)$ patients were $<18$ month of age, thirty $(52,6 \%)$ patients were $>18$ month of age. MYCN amplification appeared in $12(21 \%)$ tumour specimens.

\section{Conclusions}

Fluorescent in situ hybridization is a high-sensitive, useful technique for detecting MYCN amplification on paraffin- embedded tissue section of neuroblastoma tumours thus facilitating therapeutic decisions based on the presence or absence of this important biologic marker.

\section{Background}

Neuroblastoma is a malignant tumour in children aged 0-15 years. It accounts for 8-10\% of all childhood tumours, $80 \%$ concerns children under the age of 5 years and approximately $15 \%$ of cancers deaths in children [1, 2]. Approximately 60-70 of the new incidences of each year in Poland are diagnosed [3].

Neuroblastoma derives from primitive cells of the sympathetic nervous system. It occurs in retroperitoneum, posterior mediastinum, the neck or the pelvis. The clinical symptoms in neuroblastoma depend on the tumour mass, the extent of metastases and catecholamine and vasoactive intestinal peptide secretion from tumour cells. The diagnosis of neuroblastoma is based on histopathology test results, the presence tumour cells in bone marrow accompanied by elevated levels of urinary catecholamines. In addition, clinical, histopathological and laboratory data, there are important the genetic test results, in the determining prognosis $[4,5]$.

The most common cytogenetics changes including deletions of chromosome $1 \mathrm{p}$, amplification of the oncogene $M Y C N$, ploidy changes, gains of chromosome arm 17q and deletion of 11q in tumour cells. The 
genetic abnormalities are very powerful predictors of response to therapy and outcome and provides important information that guides optimal patient management $[6,7]$

The MYCN gene is a cellular protooncogene of the MYC family. MYCN maps to $2 \mathrm{p} 24$ chromosome where it is retained in a single copy during amplification. Amplicons containing the $M Y C N$ gene range in size from $100 \mathrm{kbp}$ to $1 \mathrm{Mbp}$ and form multiple tandem arrays present in two types of aberrant chromatin structures: double minute chromosomes (dmins) and homogeneously staining regions (HSRs). Dmins are often seen as small extra chromosomes in direct metaphase preparations from neuroblastomas, whereas HSRs are integrated as extra segments in abnormal chromosomes and are typically found in established neuroblastoma cell lines $[8,9]$.

MYCN is an oncogenic transcription factor which function in the regulation of proliferation, transformation, differentiation and apoptosis [1].

Amplification $M Y C N$ is detected in $20-30 \%$ neuroblastoma patients [10, 11]. It is strongly correlated with advanced stage of disease, rapid tumour progression, resistant to chemotherapy and poor outcome independent of patient age and stage of advanced disease. MYCN amplification test result is included in the medical protocols throughout the world and it is an independent indicator in the assessment of patient outcome and it is one of the qualifying factors to a group requiring the most aggressive treatment $[12,13,14,15,16]$. Amplification MYCN is present in $38 \%$ of patients with stages 3 and 4 [13] but only 5$10 \%$ of patients with stages 1, 2 and 4s [17]. The level of $M Y C N$ gene amplification is necessary to avoid either under- or over-treating patients [18].

The aim of this study was a standardization of the method to evaluation MYCNamplification on paraffinembedded tissue sections of neuroblastoma patients.

\section{Patients}

The test material were paraffin- embedded tissue sections with fresh remove tumours, as well as archival sections 57 patients with an established clinical diagnosis of neuroblastoma (28 females and 29 males; median age: 3 years 2 month). All of the children were admitted to the Department of Pediatric Hematology, Oncology and Transplantology, Children's University Hospital, Lublin, Poland from 1994 to 2019.

The collected clinical data included the patient's age at diagnosis, stage according to INSS (International Neuroblastoma Staging System) criteria [19], tumour location, histopathological diagnosis of the examined tissues and MYCNamplification [Table 1]. All studies were performed in the 2002-2019.

\section{Methods}

We were used Pretreatment Kit (Vysis) and LSI N-MYC (2p24) SpectrumGreen/CEP 2 SpectrumOrange Probe (Vysis) to estimate MYCN amplification. 
Paraffin-embedded tissue blocks were cut into 4-micron thick sections on silanized slides and they were baked at $56^{\circ} \mathrm{C}$ overnight. Slides were soaked twice in xylene for 10 minutes and were dehydrated in ethanol $100 \%, 96 \%, 80 \%, 70 \%$ for $2-5$ minutes in each solution. Then slides were immersed to $0,2 \mathrm{~N}$ hydrochloric acid for 20 minutes and were rinsed in water and wash buffer for 3 minutes in each of them. The slides were immersed in Pretreatment Solution at $80^{\circ} \mathrm{C}$ for 30 minutes and they were washed twice in 2xSSC for 5 minutes.

The next step was digesting tissue sections in protease solution in a $37^{\circ} \mathrm{C}$ for 30 minutes and immersed slides in 2xSSC cooled to $5^{\circ} \mathrm{C}$.

Then we were used the $10 \%$ formalin for 10 minutes for fixed tissue, were washed twice in 2xSSC and were dried slides on a $45-50{ }^{\circ} \mathrm{C}$ hot plate.

For the detection of the presence of $M Y C N$ gene amplification, on paraffin- embedded tissue section from neuroblastoma tumour, we have used the fluorescence in situ hybridization (FISH) on interphase nuclei. The FISH is the method of molecular cytogenetic, which is used to identify a specific DNA sequences on chromosomes by DNA probes which are direct labelling by fluorophore. The labelled probe and the target DNA are denatured in the first step of this method. The hybridization is the second step of FISH method. Combining the denatured probe and target DNA allows the annealing of complementary DNA sequences.

We were used $1 \mu \mathrm{l}$ direct fluorochrome- labelled, dual colour DNA Probe for the $M Y C N$ gene locus (2p24) and a-satellite DNA identifying the centromeric region of chromosome 2 (Vysis LSI N-MYC (2p24) SpectrumGreen/CEP 2 SpectrumOrange Probe) combine with the $7 \mu$ l Hybridization Buffer and $2 \mu$ water on the slide. Probe were placed on the slide under a coverslip and ringed rubber cement. The slides were incubated at $72^{\circ} \mathrm{C}$ for 5 minutes to denature the DNA. Hybridization was done for $14-18$ hours in $37^{\circ} \mathrm{C}$.

After that the slides were immersed in post- hybrydization wash buffer in room temperature for 15-20 minutes until the coverslip dropped out. Then the slides were immersed in post- hybridization wash buffer warmed to $72^{\circ} \mathrm{C}$ for 5 minutes. Cells were counterstained with DAPI. The signals were scored by eye or captured with Applied Spectral Imaging- ASI- Israel at 100x magnification on the Nikon epifluorescence microscope equipped with a 100-W mercury arc lamp and appropriate set of filters (single filters for FITC and TexasRed fluorochromes and a triple band pass filter for FITC/TR/DAPI). At least 200 nuclei were evaluated for each of the MYCN and CEP2 loci. Nuclei with two visibly red and two green signals were scored as a negative $M Y C N$ amplification (Figure 1). Nuclei with more of 10 green signals, were scored as a positive $M Y C N$ amplification (Figure 2).

The study was approved by the Ethics Committee of the Medical University of Lublin (KE0254/229/2012).

\section{Results}


Fifty-seven patients participated in this study. Twenty-eight $(49,1 \%)$ of patients had localized neuroblastoma (1-3 stages), 5,3\% stage $4 S$, and $45,6 \%$ stage 4 disease. Thirty-eight $(66,7 \%)$ of patients had got abdominal/adrenal mass at diagnosis. Twenty-seven $(47,4 \%)$ patients were $<18$ month of age, thirty $(52,6 \%)$ patients were $>18$ month of age. Of 57 patient samples comprising 43 neuroblastomas, 10 ganglioneuroblastomas, 1 ganglioneuroma. 3 samples had no definitive diagnosis.

Positive results of $M Y C N$ amplification were observed in twelve patients' paraffin-embedded tissue sections, which represents an $21 \%$ of all tested patients in the analysis.

There were 7 (55\%) males and 5 (45\%) females. Of the 12 patients, 1 (8,33\%) was in stage 3 and 1 $(8,33 \%)$ was in stage $4 \mathrm{~s}$ disease, $10(83,33 \%)$ were in stage 4 disease. Of these 12 patients with $M Y C N$ amplifications $4(33,33 \%)$ were $<18$ month of age, $8(66,67 \%)$ were $>18$ month of age. Three $(25 \%)$ of patients with $M Y C N$ amplification had tumour mass in the abdomen and nine (75\%) had tumour location in the adrenal gland.

\section{Discussion}

In many trials, high-risk patients are identified by the presence of $M Y C N$ amplification. Amplification MYCN is powerful prognostic factor of advanced stages and rapid tumour progression [20]. Interphase FISH analysis provides a direct and rapid method. Only a small number of tumour cells are required, compared with primary tumour biopsies, and FISH is more sensitive, counting the MYCN copy number in each single cell $[21,22]$.

Fluorescent in situ hybridization (FISH) method is faster to prepare than molecular biology techniques or traditional cytogenetic analysis. There is no need to isolation of DNA from tumour cells, which previously could be separate from health tissue. There is no need to take a section of the tumour immediately after the surgery to the FISH study. This can identify mixed cell populations [23, 24]. FISH can be used on interphase nuclei, in contrast to karyotype analysis, and it can be performer on formalin-fixed nuclei, in cases where fresh or frozen tumour is not available (eg. small biopsies or retrospective studies). However molecular methods such as Southern blotting and quantitative DNA polymerase chain reaction (PCR) analyse DNA pooled from a mixture of cells and therefore provide only an average result for a particular tumour. When a tumour is highly amplified, this presents no problem in diagnosis. However, with low levels of $M Y C N$ amplification, it can be difficult interpretation of results. First it may be a heterogeneous population of tumour cells in which a small amount of cells is highly amplified. Secondly a highly amplified tumour mixed with normal tissue. Thirdly a low level of amplification that occurs in tumour cells (eg. a triploid population). The first two situations would suggest a poor prognosis, whereas triploid tumours have a favourable prognosis. All of them would be regarded as non-amplified for treatment purposes. [25, 26].

The FISH technique also has disadvantages. This method requires the use of specialized equipment to view the slides such as fluorescent microscope with camera and specialized software. Finally, as tumour cells are usually dissociated from each other as part of the FISH technique, information about tissue 
architecture is lost, and it is difficult, if not impossible, to distinguish normal cells from tumour cells [26, 27].

In polish population tumour touch imprints are routinely used to assess $M Y C N$ amplification. However, this is not always possible and then the only material for MYCN amplification assessment are paraffin tissue section. The removed tumour is in the whole embedded in paraffin and used for many studies, including histopathological, immunohistochemical and genetic tests. It can be made both on the fresh and archival tissues for many years ago.

For this study we were used fresh paraffin- embedded tissue sections as well as archival materials. A fresh material was made from a tumour which was removed from a patient 2 weeks before the study and archival paraffin section was removed from a patient operated 8 years and 2 months before the test. In our opinion both fresh tissues and those from many years ago preserved in a paraffin block were a fullfledged material for the test. The quality of the preparations was similar and evaluation of both archival and fresh ones was corresponds to previous studies.

In the literatures, high-risk patients had long-term survival of only $10-20 \%$ with combination chemiotherapy, surgery and local radiation therapy [28]. However, treatment approaches that used a combination of induction therapy, myeloablative consolidation therapy with stem cell support, and biologic therapy had improved 5-year survival rates from less than $15 \%-40 \%$ [29].

Despite many biochemical, molecular and genetics indicators as a marker of poor prognosis, MYCN amplification still feature in patient stratification to the risk group and it is the marker of poor prognosis. These patients respond poorly to conventional therapy. The possibility of determining this biological marker is necessary for appropriate clinical management. Unfortunately, treatment failure has been reported in all patient groups, even without $M Y C N$ amplification, suggesting additional prognostic markers must be discovered to improve treatments protocols [30].

\section{Declarations}

\section{Ethics Approval and Consent to Participate}

The study was approved by the Ethics Committee of the Medical University of Lublin (KE0254/229/2012).

All of participants have written consent to participate and publish the data. All procedures performed in studies involving human participants were in accordance with the ethical standards of the institutional and/or national research committee and with the 1964 Helsinki declaration and its later amendments or comparable ethical standards. Informed consent was obtained from all individuals included in the study and their parents or guardians on behalf of any participant under the age of 16 .

\section{Consent for publication}


Not applicable.

\section{Availability of data and materials}

Data and material are available upon request.

Dorota Winnicka e-mail: dwinnicka@o2.pl

\section{Competing interests}

The authors declare that they have no competing interests.

\section{Funding}

No funding

\section{Authors' contribution}

DW and ML are responsible for the conception and design of the study. JZ shared patients' clinical data. DW and MB conducted laboratory work. BS and PS were responsible for the acquisition of literatures for manuscript. DW and MB were responsible for interpretation of data. DW and ML prepared final manuscript for publication. The final manuscript was reviewed and approved by all authors.

\section{Acknowledgements}

Not applicable.

\section{References}

1. 1. van Noesel MM, Versteeg R. Pediatric neuroblastomas: genetic and epigenetic 'danse macabre'. Gene. 2004; 21:325:1-15. doi: 10.1016/j.gene.2003.09.042. PMID: 14697505.

2. Park JR, Eggert A, Caron H. Neuroblastoma: biology, prognosis, and treatment. Pediatr Clin North Am. 2008; 55(1):97-120, x. doi: 10.1016/j.pcl.2007.10.014. PMID: 18242317.

3. Balwierz W, Nerwiak zarodkowy współczulny. W: Zalecenia postępowania diagnostycznoterapeutycznego w nowotworach złośliwych - 2011 r. (Część 2) red. Maciej Krzakowski, Wiesław Jędrzejczak, Jerzy R. Kowalczyk, Via Medica, Gdańsk 2012;827-843.

4. Simon T, Hero B, Hunneman DH, Berthold F. Tumour markers are poor predictors for relapse or progression in neuroblastoma. Eur J Cancer. 2003; 39(13):1899-903. doi: 10.1016/s09598049(03)00376-9. PMID: 12932669.

5. Adamkiewicz - Drożyńska E, Ocena znaczenia wybranych wskaźników proliferacji i angiogenezy w guzach z grupy nerwiaka zarodkowego współczulnego dla prognozowania klinicznego. Ann Acad Med Gedanensis 2006; 5:1- 
6. Lim H, Son MH, Hyun JK, Cho HW, Ju HY, Lee JW et al. Clinical Significance of Segmental Chromosomal Aberrations in Patients with Neuroblastoma: First Report in Korean Population. J Korean Med Sci. 2020; 13;35(14):e82. doi: 10.3346/jkms.2020.35.e82. PMID: 32281311; PMCID: PMC7152533.

7. Bown N. Neuroblastoma tumour genetics: clinical and biological aspects. J Clin Pathol. 2001; 54(12):897-910. doi: 10.1136/jcp.54.12.897. PMID: 11729208; PMCID: PMC1731335.

8. Schwab M. MYCN in neuronal tumours. Cancer Lett. 2004; 20;204(2):179-87. doi: 10.1016/S03043835(03)00454-3. PMID: 15013217.

9. Westermann F, Schwab M, Genetic parameters of neuroblastoma. Cancer Lett 2002; 184:127 -

10. Schnepp RW, Maris JM. Targeting MYCN: a good BET for improving neuroblastoma therapy? Cancer Discov. 2013; 3(3):255-7. doi: 10.1158/2159-8290.CD-13-0018. PMID: 23475876; PMCID: PMC3709873.

11. Yue ZX, Huang C, Gao C, Xing TY, Liu SG, Li XJ et al. MYCNamplification predicts poor prognosis based on interphase fluorescence in situ hybridization analysis of bone marrow cells in bone marrow metastases of neuroblastoma. Cancer Cell Int. 2017;31;17:43. doi: 10.1186/s12935-017-0412-z. PMID: 28367105; PMCID: PMC5374581.

12. Schwab M. Amplification of N-myc as a prognostic marker for patients with neuroblastoma. Semin Cancer Biol. 1993;4(1):13-8. PMID: 8448374.

13. Brodeur GM, Seeger RC, Schwab M, Varmus HE, Bishop JM. Amplification of N-myc in untreated human neuroblastomas correlates with advanced disease stage. 1984; 224(4653):1121-4. doi: 10.1126/science.6719137. PMID: 6719137.

14. Brodeur GM, Seeger RC, Schwab M, Varmus HE, Bishop JM. Amplification of N-myc sequences in primary human neuroblastomas: correlation with advanced disease stage. Prog Clin Biol Res. 1985;175:105-13. PMID: 3991726.

15. Seeger RC, Brodeur GM, Sather H, Dalton A, Siegel SE, Wong KY et al. Association of multiple copies of the N-myc oncogene with rapid progression of neuroblastomas. N Engl J Med. 1985; 313(18):1111-6. doi: 10.1056/NEJM198510313131802. PMID: 4047115.

16. Davidoff AM. Neuroblastoma. Semin Pediatr Surg. 2012 Feb;21(1):2-14. doi: 10.1053/j.sempedsurg.2011.10.009. PMID: 22248965; PMCID: PMC3261589.

17. Brodeur GM, Fong CT. Molecular biology and genetics of human neuroblastoma. Cancer Genet Cytogenet. 1989;41(2):153-74. doi: 10.1016/0165-4608(89)90243-4. PMID: 2673506.

18. Lee JW, Son MH, Cho HW, Ma YE, Yoo KH, Sung KW et al. Clinical significance of MYCN amplification in patients with high-risk neuroblastoma. Pediatr Blood Cancer. 2018 Oct;65(10):e27257. doi: 10.1002/pbc.27257. Epub 2018 May 24. PMID: 29797634.

19. Brodeur GM, Pritchard J, Berthold F, Carlsen NL, Castel V, Castelberry RP et al. Revisions of the international criteria for neuroblastoma diagnosis, staging, and response to treatment. J Clin Oncol. 1993 Aug;11(8):1466-77. doi: 10.1200/JC0.1993.11.8.1466. PMID: 8336186. 
20. Lau DT, Flemming CL, Gherardi S, Perini G, Oberthuer A, Fischer et al. MYCN amplification confers enhanced folate dependence and methotrexate sensitivity in neuroblastoma. Oncotarget. 2015; 20;6(17):15510-23. doi: 10.18632/oncotarget.3732. PMID: 25860940; PMCID: PMC4558167.

21. Tibiletti MG. Interphase FISH as a new tool in tumor pathology. Cytogenet Genome Res. 2007;118(24):229-36. doi: 10.1159/000108305. PMID: 18000375.

22. Wang M, Zhou C, Cai R, Li Y, Gong L. Copy number gain of MYCN gene is a recurrent genetic aberration and favorable prognostic factor in Chinese pediatric neuroblastoma patients. Diagn Pathol. 2013; 15;8:5. doi: 10.1186/1746-1596-8-5. PMID: 23320395; PMCID: PMC3567989.

23. Ambros PF, Ambros IM, Kerbl R, Luegmayr A, Rumpler S, Ladenstein R et al. Intratumoural heterogeneity of $1 \mathrm{p}$ deletions and MYCN amplification in neuroblastomas. Med Pediatr Oncol. 2001;36(1):1-4. doi: 10.1002/1096-911X(20010101)36:1<1::AID-MP01002>3.0.CO;2-L. PMID: 11464855.

24. Tibiletti MG. Specificity of interphase fluorescence in situ hybridization for detection of chromosome aberrations in tumor pathology. Cancer Genet Cytogenet. 2004;155(2):143-8. doi:

10.1016/j.cancergencyto.2004.03.005. PMID: 15571800.

25. Thorner PS, Ho M, Chilton-MacNeill S, Zielenska M. Use of chromogenic in situ hybridization to identify MYCN gene copy number in neuroblastoma using routine tissue sections. Am J Surg Pathol. 2006; 30(5):635-42. doi: 10.1097/01.pas.0000202163.82525.5c. PMID: 16699319.

26. Shapiro DN, Valentine MB, Rowe ST, Sinclair AE, Sublett JE, Roberts WM et al. Detection of N-myc gene amplification by fluorescence in situ hybridization. Diagnostic utility for neuroblastoma. Am J Pathol. 1993; 142(5):1339-46. PMID: 7684192; PMCID: PMC1886925.

27. Squire JA, Thorner P, Marrano P, Parkinson D, Ng YK, Gerrie B et al. Identification of MYCN Copy Number Heterogeneity by Direct FISH Analysis of Neuroblastoma Preparations. Mol Diagn. 1996 Dec;1(4):281-289. doi: 10.1054/MODI00100281. PMID: 10462574.

28. Matthay KK. Neuroblastoma: a clinical challenge and biologic puzzle. CA Cancer J Clin. 1995 MayJun;45(3):179-92. doi: 10.3322/canjclin.45.3.179. PMID: 7743421.

29. Shusterman S, George RE: Neuroblastoma. Edited by: Orkin SH, Fisher DE, Look AT, Lux SE, Ginsburg D, Nathan DG. Oncology of infancy and childhood; 2009: Chapter 14:509-540.

30. Maris JM. Recent advances in neuroblastoma. N Engl J Med. 2010; 10;362(23):2202-11. doi: 10.1056/NEJMra0804577. PMID: 20558371; PMCID: PMC3306838.

\section{Tables}

Table 1. Characteristics of patients. 


\begin{tabular}{|c|c|c|c|c|c|}
\hline Patient & Age at diagnosis & Diagnosis & INSS risk group & Primary site & MYCN amplification \\
\hline 1. & $<18 m$ & NB & 3 & pelvis & No \\
\hline 2. & $>18 \mathrm{~m}$ & NB & 4 & abdomen & No \\
\hline 3. & $<18 m$ & GNB & 4 & abdomen & No \\
\hline 4. & $>18 \mathrm{~m}$ & GNB & 4 & abdomen & No \\
\hline 5. & $>18 \mathrm{~m}$ & NB & 4 & abdomen & No \\
\hline 6. & $>18 \mathrm{~m}$ & NB & 4 & mediastinum & No \\
\hline 7. & $>18 \mathrm{~m}$ & GNB & 3 & adrenal & Yes \\
\hline 8. & $<18 m$ & GNB & 1 & pelvis & No \\
\hline 9. & $<18 \mathrm{~m}$ & NB & 4 & adrenal & Yes \\
\hline 10. & $<18 \mathrm{~m}$ & NB & 3 & pelvis & No \\
\hline 11. & $>18 \mathrm{~m}$ & NB & 4 & abdomen & Yes \\
\hline 12. & $<18 m$ & GNB & 3 & mediastinum & No \\
\hline 13. & $<18 m$ & NB & 2 & mediastinum & No \\
\hline 14. & $>18 \mathrm{~m}$ & GN & 3 & mediastinum & No \\
\hline 15. & $<18 m$ & NB & 4 & pelvis & No \\
\hline 16. & $>18 \mathrm{~m}$ & NB & 2 & mediastinum & No \\
\hline 17. & $>18 \mathrm{~m}$ & NB & 3 & abdomen & No \\
\hline 18. & $>18 \mathrm{~m}$ & NB & 4 & abdomen & No \\
\hline 19. & $<18 m$ & NB & 3 & adrenal & No \\
\hline 20. & $>18 \mathrm{~m}$ & NB & 4 & abdomen & No \\
\hline 21. & $<18 m$ & NB & 3 & mediastinum & No \\
\hline 22. & $<18 m$ & NB & 1 & adrenal & No \\
\hline 23. & $>18 \mathrm{~m}$ & NB & 4 & abdomen & No \\
\hline 24. & $<18 m$ & NB & 3 & mediastinum & No \\
\hline 25. & $<18 m$ & NB & $4 s$ & cervical & No \\
\hline 26. & $<18 m$ & NB & 4 & adrenal & Yes \\
\hline 27. & $>18 \mathrm{~m}$ & GNB & 3 & mediastinum & No \\
\hline 28. & $<18 m$ & ND & 3 & mediastinum & No \\
\hline
\end{tabular}




\begin{tabular}{|c|c|c|c|c|c|}
\hline 29. & $>18 \mathrm{~m}$ & NB & 4 & abdomen & No \\
\hline 30. & $>18 \mathrm{~m}$ & NB & 4 & adrenal & Yes \\
\hline 31. & $>18 \mathrm{~m}$ & NB & 3 & pelvis & No \\
\hline 32. & $>18 \mathrm{~m}$ & NB & 1 & mediastinum & No \\
\hline 33. & $>18 \mathrm{~m}$ & NB & 4 & adrenal & No \\
\hline 34. & $>18 \mathrm{~m}$ & NB & 3 & adrenal & Yes \\
\hline 35. & $>18 \mathrm{~m}$ & NB & 3 & abdomen & No \\
\hline 36. & $>18 \mathrm{~m}$ & ND & 4 & adrenal & Yes \\
\hline 37. & $<18 \mathrm{~m}$ & NB & $4 s$ & adrenal & Yes \\
\hline 38. & $>18 \mathrm{~m}$ & NB & 4 & adrenal & Yes \\
\hline 39. & $<18 \mathrm{~m}$ & NB & 3 & adrenal & No \\
\hline 40. & $<18 \mathrm{~m}$ & ND & 1 & mediastinum & No \\
\hline 41. & $<18 \mathrm{~m}$ & NB & 1 & adrenal & No \\
\hline 42. & $<18 \mathrm{~m}$ & NB & 3 & pelvis & No \\
\hline 43. & $<18 \mathrm{~m}$ & NB & 4 & adrenal & No \\
\hline 44. & $>18 \mathrm{~m}$ & NB & 4 & adrenal & Yes \\
\hline 45. & $>18 \mathrm{~m}$ & GNB & 1 & adrenal & No \\
\hline 46. & $>18 \mathrm{~m}$ & NB & 3 & abdomen & No \\
\hline 47. & $<18 \mathrm{~m}$ & NB & 3 & pelvis & No \\
\hline 48. & $>18 \mathrm{~m}$ & GNB & 4 & adrenal & No \\
\hline 49. & $<18 \mathrm{~m}$ & NB & $4 s$ & adrenal & No \\
\hline 50. & $<18 \mathrm{~m}$ & NB & 3 & adrenal & No \\
\hline 51. & $>18 \mathrm{~m}$ & GNB & 4 & adrenal & No \\
\hline 52. & $>18 \mathrm{~m}$ & NB & 3 & abdomen & No \\
\hline 53. & $>18 \mathrm{~m}$ & NB & 4 & abdomen & Yes \\
\hline 54. & $<18 m$ & NB & 4 & adrenal & No \\
\hline 55. & $<18 m$ & NB & 4 & abdomen & Yes \\
\hline 56. & $<18 \mathrm{~m}$ & NB & 4 & adrenal & No \\
\hline 57. & $>18 \mathrm{~m}$ & GNB & 4 & abdomen & No \\
\hline
\end{tabular}


$\mathrm{M}$ - male, F - female, m-month, NB - neuroblastoma

GNB - ganglioneuroblastoma, GN - ganglioneuroma, ND - no data,

INSS - International Neuroblastoma Staging System

\section{Figures}

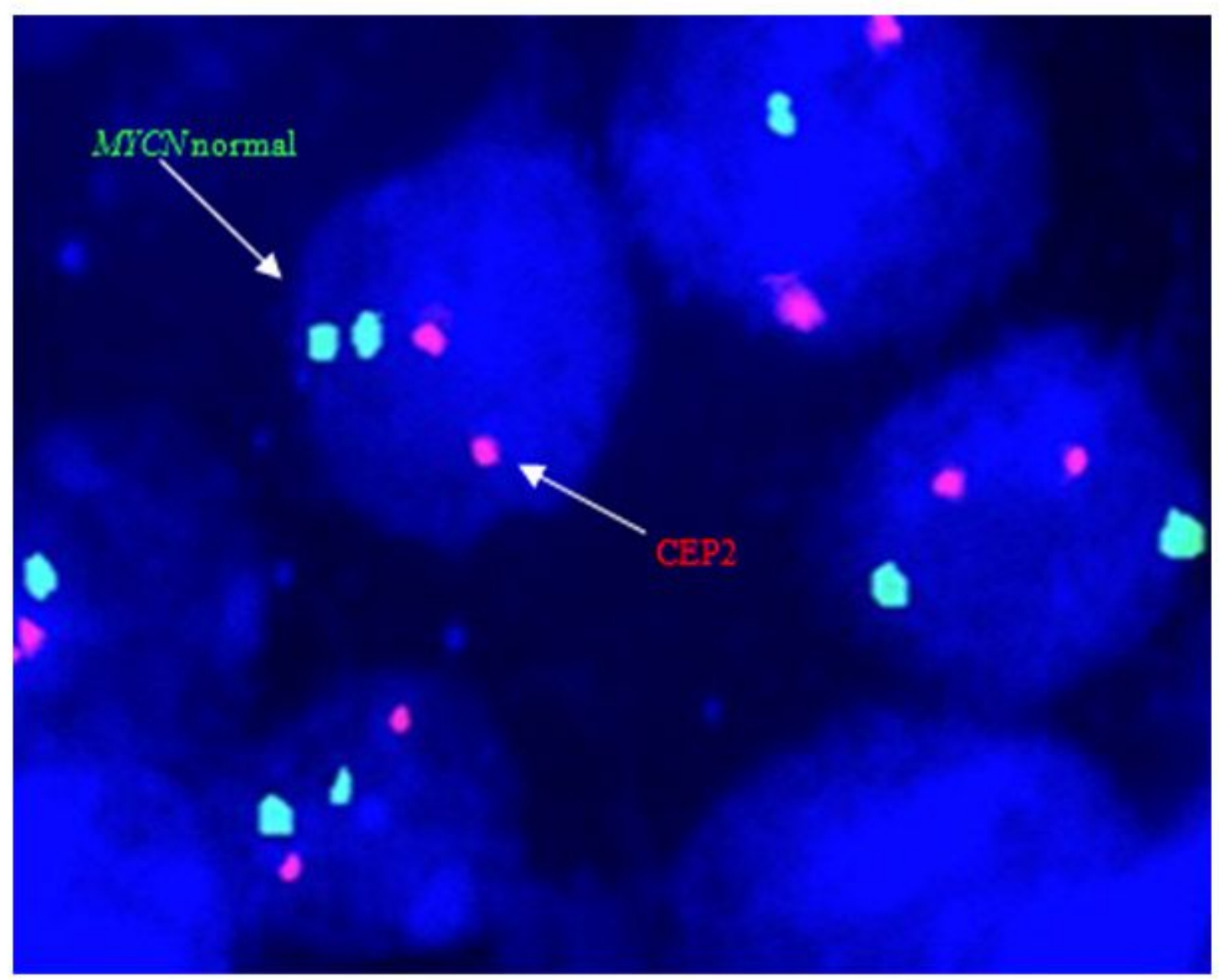

Figure 1

Representative FISH image on paraffin-embedded tissue section using Vysis LSI N-MYC (2p24) SpectrumGreen/CEP 2 SpectrumOrange Probe from neuroblastoma tumour showing normal interphase nuclei captured with Applied Spectral Imaging- ASI-Israel at 100x magnification on the Nikon epifluorescence microscope. 


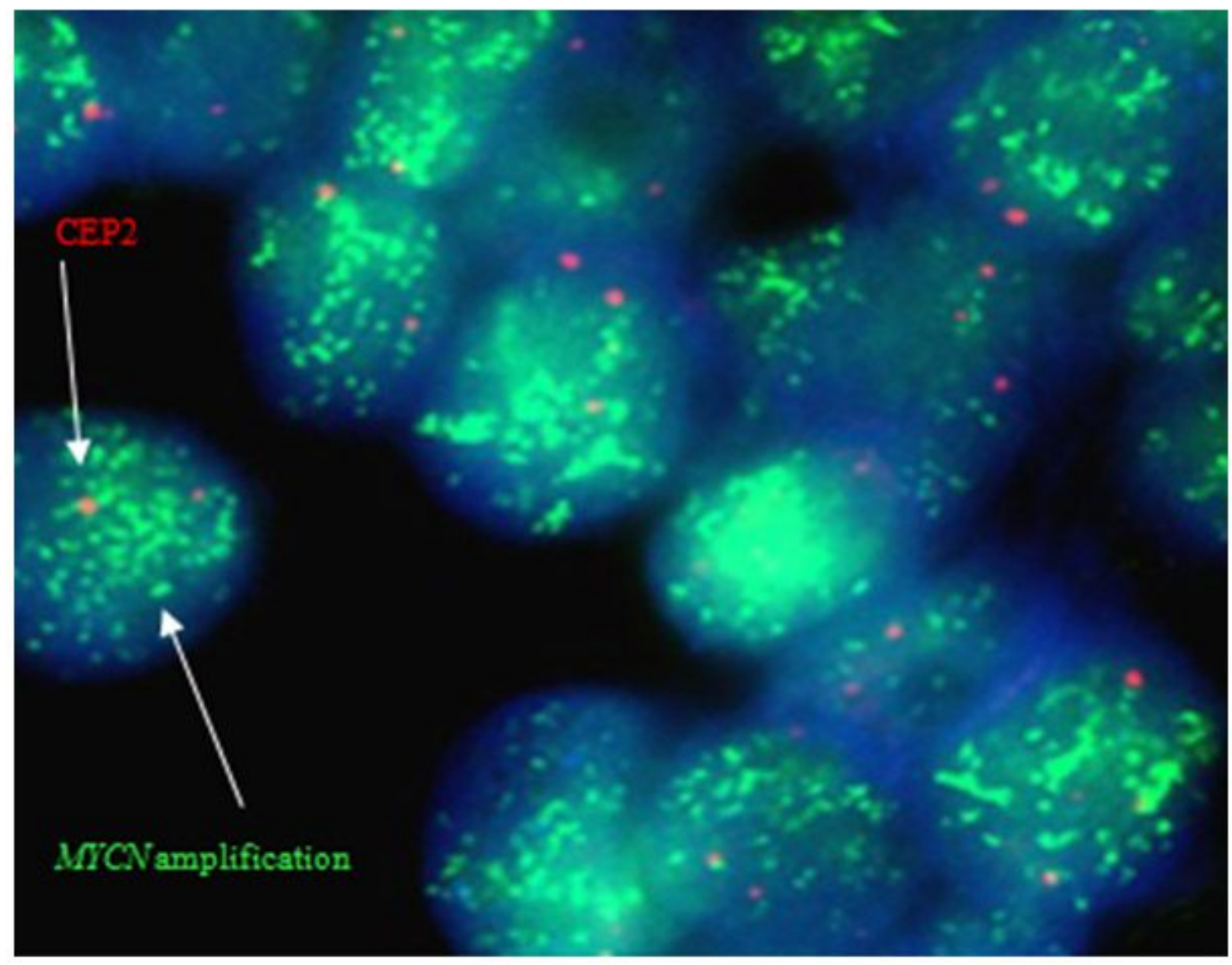

\section{Figure 2}

Representative FISH image on paraffin-embedded tissue section using Vysis LSI N-MYC (2p24) SpectrumGreen/CEP 2 SpectrumOrange Probe from neuroblastoma tumour showing amplification MYCN captured with Applied Spectral Imaging- ASI- Israel at 100x magnification on the Nikon epifluorescence microscope. 